\title{
E-Commerce in Strengthening The Economy During The Covid- 19 Pandemic: A Historical Review
}

\author{
Arelia Dianda ${ }^{1}$ and Moses Glorino Rumambo Pandin ${ }^{2}$ \\ ${ }^{1,2}$ Airlangga University, Surabaya, Indonesia \\ Email: arelia.dianda-2020@fib.unair.ac.id; moses.glorino@fib.unair.ac.id

\begin{tabular}{|l|}
\hline \\
\hline How to cite (in APA style): \\
Dianda, A., \& Pandin, M. G. R. (2021). E-Commerce in Strengthening The Economy During The Covid-19 Pandemic: A \\
Historical Review. Jurnal Ekonomi dan Bisnis Jagaditha, 8(2), 179-186. doi: https://doi.org/10.22225/jj.8.2.2021.179-186 \\
\hline
\end{tabular}

\begin{abstract}
The Covid-19 pandemic bears some resemblance to the Spanish Flu outbreak that occurred in the 20th century. The impact of the Covid-19 pandemic has its own way of dealing with it, for example, there are application sites that can accommodate micro and small entrepreneurs who are affected by Covid-19, namely e-commerce. This study aims to examine the role of e-commerce in strengthening the economy during the Covid-19 pandemic and review it from a historical perspective. This study used a qualitative descriptive method, meanwhile the data of this study data consisting of 19 articles and 1 website. The results of this study revealed that there is an increase in the number of e-commerce access during the Covid-19 pandemic. This shows that e-commerce can help the community in several aspects, one of which is strengthening economic aspects during the Covid-19 pandemic. In addition, there are similarities between the current pandemic situation and the Spanish Flu outbreak experienced during the Dutch colonial period. This research is expected to be a reference for people who want to know about the role of e-commerce during the pandemic.
\end{abstract}

Keywords: Covid-19; E-commerce; Economy

\section{INTRODUCTION}

The world has recorded a new history of events that shocked the whole world at the end of 2019. The incident began with the emergence of a new virus that is a new variant of coronavirus and was first discovered in Wuhan, China, and spread massively to various parts of the country (Valerisha \& Putra, 2020). The virus is called Severe Acute Respiratory Syndrome Coronavirus-2 (SARSCoV-2) (Susilo et al., 2020) and causes a new outbreak of the disease termed the COVID-19 outbreak. Common symptoms of infection by infected individuals are headache, phlegm cough, hemoptysis, and diarrhea (Ridlo, 2020). The massive spread of the virus causing COVID-19 disease is categorized as a pandemic by the World Health Organization (WHO).

A Covid-19 disease that spread rapidly makes Indonesia one of the countries experiencing the disease outbreak. COVID-19 causes various impacts in various aspects, such as health, economy, and education. The Government of Indonesia has made various considerations to maintain aspects of life so as not to experience deterioration. The policy that has been done by the Indonesian government is the Pembatasan Sosial Berskala BesaR (PSBB) policy, which is a policy that makes people's mobility limited in order to minimize the spread of the COVID-19 virus. Pembatasan Sosial Berskala Besar (PSBB) is listed in Peraturan Pemerintah (Government Regulations) Number 21 of 2020 (Tuwu, 2020).

The Indonesian government's policy on large-scale social restrictions is an effort to reduce the spread of COVID-19. In each policy, there are risks in its determination. In this case, the policy has a drastic impact on the economic sector. In the economic sector, both small and large businesses are affected by the COVID-19 pandemic. Businesses consider the business or health of the workers. Therefore, the government recommends that businesses hire employees of a company to work from 
home only (WFH) (Purwanto, 2020). However, businesses that have deteriorated in terms of business income will do dismissal or termination of work from those employees. This causes the unemployment rate to grow as a result of the termination of employment rights. Therefore, individuals who experience termination of employment rights are encouraged to open or set up their own businesses to earn income and improve the Indonesian economy. Individuals who experience layoffs, can look for other alternatives by utilizing technological advances to increase income, for example selling through e-commerce. The issue regarding the role of e-commerce in strengthening the economy during the COVID19 pandemic is important to study because through this the public can know that ecommerce has benefits that can be used to increase income.

Independent businesses established by a person or group of people are currently popular to be marketed through online media. Online media can be either social media or ecommerce that becomes a container of sellers and buyers to make transactions. E-commerce or electronic commerce is part of e-business, in addition to using network technology, also using electronic mail, database technology, and other forms of non-computer technology, such as payment methods and shipping methods. E-business is believed to be broader because it includes consumer services, a collaboration between business partners supported by electronic media as a means of transaction (Fauzi, Al-Khowarizmi, \& Muhathir, 2020). E-commerce is the impact of globalization affecting Indonesia. Globalization itself is the entry of foreign cultural influences into a country. The impact of globalization can be categorized into positive and negative impacts. The positive impact that can now be felt in Indonesia is the development of technology that facilitates daily life, such as working, studying, to meet daily needs or can be termed by shopping for daily needs.

E-commerce is used as a place to conduct transactions between sellers and buyers. Ecommerce is chosen by manufacturers and consumers because there are various conveniences offered by the application site. Moreover, during the COVID-19 pandemic, the government recommends that people stay at home or do activities at home to minimize the transmission of COVID-19. Therefore, people choose to meet their needs online through e-commerce application sites and market products sold through the application site. In addition, e-commerce makes a source of income from some circles and thus ecommerce serves as an economic booster, especially during the COVID-19 pandemic.

Some related studies have conducted about E-Commerce during Covid-19 previously. (Mandasari \& Pratama, 2020) in their study about 'the effect of e-commerce on the income and sales volume of MSMEs in Denpasar City' revealed that E-Commerce has a positive and significant effect on income; this means that using e-commerce during the COVID-19 pandemic can increase income. Meanwhile, a study conducted by Saturwa et al. (2021) about 'the impact of Covid-19 on MSMEs' performance in former Pekalongan Residency, as measured by the sales turnover, labor, and business cash flow resilience' showed that Covid-19 has negatively affected MSMEs' sales performance at the Pekalongan Ex-Residency. Sectorally, Covid-19 largely affects MSMEs in the retail trade and food and beverage provision. However, MSMEs in these sectors exhibit the best cash flow resilience than firms in other sectors. These firms also reduce their employees to a lesser extent. Covid-19 largely affects micro firms. However, micro firms have the best cash flow resilience relative to medium and small firms. They also have relatively low employee reduction. MSMEs expect that the government offers a capital stimulus to help them survive the Covid-19 pandemic. Based on the previous studies above, it can be asserted that during the Covid-19, E-Commerce has a significant effecr and another study showed that the Covid-19 has negative effect on MSMEs sale performance. Hence, this study aims to examine the role of e-commerce in strengthening the economy during the Covid19 pandemic and review it from a historical perspective.

\section{CONCEPT AND HYPOTHESIS}

\section{COVID-19 pandemic}

The COVID-19 pandemic is a pandemic created by the massive spread of the Severe Acute Respiratory Syndrome Coronavirus 2 (SARS-CoV-2). This virus was first detected in Wuhan, China and spread widely to several countries. The massive spread of this virus has made it difficult for several countries in the world to deal with the spread of this virus. The symptoms are similar to those of the common cold, such as dizziness, fever, cough, runny nose, and a particular symptom is a 
malfunctioning sense of smell and taste. This very fast spread makes WHO categorize it as a pandemic status. Indonesia is one example of a country experiencing obstacles in handling cases of the COVID-19 pandemic. This pandemic affects various aspects, such as aspects of education, politics, and even the economy. The government has implemented various policies to minimize the spread of the virus. The policies made take into account various aspects, although there are some groups who consider these policies to be less effective in tackling the impacts of the COVID -19 pandemic. Cooperation between the government and the community is needed to minimize the spread of the COVID-19 pandemic.

\section{Definition of E-commerce}

E-commerce is a place or place for sellers and buyers to conduct transactions through electronic media. According to Baum (1999) e -commerce is a dynamic combination of technology, business processes, and applications that will connect consumers, certain groups of communities, and companies through electronic transactions and the sale of goods, information, and services through electronic media. Through e-commerce, consumers do not need to leave the house to fulfill their needs. For producers, e-commerce can reduce their production costs, where they only need to use the internet to market their products. Various advantages derived from the existence of e-commerce make people interested in shopping or fulfilling their needs through e-commerce. There are several wellknown e-commerce in Indonesia, namely Shopee, Tokopedia, Bukalapak, Lazada, and so on. The e-commerce offers various benefits that can attract consumers to buy through the application, for example, the free shipping program, discounted prices, and cashback. This makes people interested in transacting through e-commerce. In addition, there are several types of e-commerce, namely Business to business (B2B), business to consumers $(\mathrm{B} 2 \mathrm{C})$, consumers to consumers $(\mathrm{C} 2 \mathrm{C})$, and consumer to business (C2B). Through ecommerce, people can continue their lives, where they can make e-commerce their main source of income to earn money. So with this, e-commerce is quite influential on the economic system in Indonesia.

\section{Spanish Flu Pandemic}

About 100 years ago there was an outbreak of a dangerous disease, namely the Spanish Flu. This disease is caused by the
H1N1 virus. The virus is thought to have come from animals, namely birds. It is estimated that this epidemic claimed the lives of 50 million people spread throughout the world and as many as 500 million people were infected with this disease. This virus is believed to be the most virulent variant of the Influenza virus, therefore this disease can claim many human lives. History records that there are two waves of the spread of this disease. The first occurred in 1918 which took place in the Kansas military area of the United States and the second wave occurred in March 1918 which was centered in Spain. The spread is quite fast, making this disease infect European countries quickly. At that time there was no vaccine or effective drug to minimize the spread of the virus. The public is ordered to wear a mask while on the move as an effort to prevent the spread of the virus. The virus is believed to have mysteriously disappeared because it was obscured by news of deaths resulting from World War I and poor historical records. This disease spread widely throughout the world, even infecting Indonesia. At that time Indonesia was being colonized by the Dutch colonial government. The Dutch colonial government at that time found it difficult to deal with this disease outbreak. They consider various ways to minimize the spread of this disease. The Dutch colonial government made several policies to minimize the spread of this disease, although there were some opposition from these policies.

The hypothesis of the research conducted is that the increasing flow of globalization triggers the development of technology. Technology exists to make it easier for humans to carry out daily activities. Technological developments that occur rapidly make the emergence of several new habits in people's lives. For example, people's shopping activities are currently undergoing changes, where some people choose to fulfill their needs through shopping applications or can be called ecommerce. E-commerce is the impact of technological developments. Currently, the world is experiencing a dangerous pandemic, namely the COVID-19 pandemic. The COVID -19 pandemic was caused by the rapid spread of the Severe Acute Respiratory Syndrome Coronavirus 2 (SARS-CoV-2). This virus was initially detected in Wuhan, China and is currently spreading widely to infect several countries in the world. This pandemic affects various aspects of life, one of which is the economic aspect. This influence is expected to be minimized by the presence of e-commerce. E-commerce has an important role in tackling 
the impact of the COVID-19 pandemic that attacks the community's economic sector. Ecommerce makes it easier for people to transact, both in terms of producers and consumers, getting a positive impact from the existence of e-commerce. The COVID-19 pandemic is a pandemic that attacks various aspects of people's lives, one of which is the economic aspect. Therefore, with the existence of e-commerce, people find it helpful to earn additional income, and even make e-commerce their main means of income.

\section{METHOD}

This study used a qualitative descriptive method. The data of this study are 19 articles and 1 website. The source of the data are obtained from literature studies published online in the last three years and reliable, such as journal articles and the Databoks website that had relevance to the topic of discussion of this study, such as discussions about ecommerce, the COVID-19 pandemic, the role of e-commerce during the COVID-19 pandemic, and the resemblance of the COVID19 pandemic to the Spanish Flu outbreak. In analyzing the data, there are several steps used (Sidiq U, 2019). These steps consist of three kinds, namely: 1) Data Reduction. At this stage, the data obtained is quite a lot and needs to be studied more deeply to get the core or main things that are relevant to the objectives of the research conducted. 2) Data Exposure. In qualitative research, data exposure can be done by providing narration and presenting data so that readers can understand the content of the research conducted. 3) Conclusion Drawing/Verification. At this stage, the researcher can make a summary containing the answers to the questions posed.

\section{RESULT AND DISCUSSION}

The results of the study are described by using the literature review method that have previously discussed or contained topics about the related discussions to this study. There ae 21 references consisting of 19 journal articles in 2020, 1 journal article in 2021, and one Databoks site in 2020 are obtained. However, only 19 journal articles and Databoks websites are used as the data of this study. The COVID19 pandemic was a pandemic caused by the Severe Acute Respiratory Syndrome Coronavirus 2 (SARS-CoV-2). The COVID19 pandemic has impacts on every sector of life, one of which is the economic aspect. This impact can be overcome by utilizing ecommerce sites to strengthen the economy as a result of the impact of the COVID-19 pandemic. When viewed from a historical perspective, the COVID-19 pandemic has similarities to the Spanish Flu outbreak that occurred in the early 20 th century.

The rapid development of technology, especially in the 21st century, makes the emergence of a variety of new methods or ways of carrying out daily activities. These methods are updated in order to create the effect of the actions that want to be done. An example of an updated method is the shopping method. In the 21 st century, online shopping methods are on the rise. It shows that online shopping is popular with the public because there are various conveniences offered through online shopping. Online shopping is the process of purchasing goods or services through electronic devices, such as smartphones, laptops, computers, and so on. Generally, online shopping is done through an application site that houses or provides a place that serves as a medium of transactions between sellers and buyers, namely through ecommerce.

E-commerce according to Baum (1999) is a dynamic combination of technology, business processes, and applications that will connect consumers, a certain group of communities, and companies through electronic transactions and the sale of goods, information, and services conducted through electronic media (Bahtiar, 2020). E-commerce can be interpreted in general as a container or place between sellers and buyers who want to make transactions online. The rapid development of technology, making ecommerce is a shopping medium that is believed to be used in the business world. This is due to the growing number of enthusiasts of online shopping methods and the growth of competitors among fellow manufacturers, so manufacturers are required to be creative in marketing their products. When referring to historical flashbacks, e-commerce appeared in 1995 when one of the internet portals with the name Netscape.com get the first ads coming from the main company and introduced and popularized that the web could be used as a new medium for advertising and sales. This resulted in a two to three times increase in sales than before and that was unexpected (Ayu \& Lahmi, 2020).

There are several types of e-commerce that can be classified according to Suyanto (2003) in Leatemia (2020). First, Business to business (B2B) has the scope of exchange between goods and services, or there is the information between businesses. Business to 
business can happen to businesses, such as manufacturers and wholesalers, or between wholesalers and retailers. Second, business to consumers (B2C) which is an e-business by selling products to consumers with a variety of software with internet media. Third, consumers to consumers $(\mathrm{C} 2 \mathrm{C})$ which is a series of activities of e-commerce between individuals who conduct transactions directly without using any business intermediaries related to internet media. Fourth, consumer to business (C2B), is an e-commerce model about businesses with an individual scope or individually conducting transactions with several companies.

\section{The Development and Role of E-Commerce During The COVID-19 Pandemic}

The COVID-19 pandemic is a pandemic caused by Severe Acute Respiratory Syndrome Coronavirus 2 (SARS-CoV-2) (Handayani, Arradini, Darmayanti, Widiyanto, \& Atmojo, 2020). With the COVID-19 pandemic, various aspects of life are changing. In terms of education, it has an impact on the creation of policies to learn from home and replace the learning system with an online or online system (Siahaan, 2020). In terms of health, pandemics have an impact on a person's physical to mental health, and in terms of economics is the termination of employment rights that are widely done by companies due to the decrease in income from companies. Mass termination of employment rights amounted to $1,943,916$ people and consisted of 114,340 companies (Yamali \& Putri, 2020). This can trigger rising unemployment and poverty rates in Indonesia. Therefore, both the government and the public are required to work together in tackling the impacts of COVID-19.

In reducing the unemployment and poverty rate, people are expected to take advantage of a platform that provides a place to start a business, both independently and in groups. The platform is e-commerce that can be an application or website that offers goods and services. Therefore, during the COVID-19 pandemic, people began to use e-commerce to market the products they sell or offer. This is because there are various conveniences offered by e-commerce.

Currently, e-commerce in Indonesia is experiencing rapid development.There has been an increase of 5 to 10 times between manufacturers and consumers through online transactions during the COVID-19 pandemic. Although before the pandemic there was an increase, but when the pandemic the increase rose quite rapidly. The increase was initially reached 3.1 million, during the pandemic increased to 4.8 million transactions (Laming, 2020). This proves that government policy, namely PSBB causes a decrease in the mobility of some people. PSBB(Pembatasan Sosial Berskala Besar) is the government's policy on restricting certain activities of people in an area considered infected with COVID-19 (Juaningsih, Consuello, Tarmidzi, \& NurIrfan, 2020). In addition, 52\% of people avoided shopping directly by visiting the seller's place during the pandemic and especially in densely populated areas and $36 \%$ responded that the respondent avoided the method of shopping physically or directly to the seller's place until getting the COVID-19 vaccine (Bhatti, Akram, \& Khan, 2020). Thus, people remain at home only and meet their needs through electronic media and internet that provide such facilities.

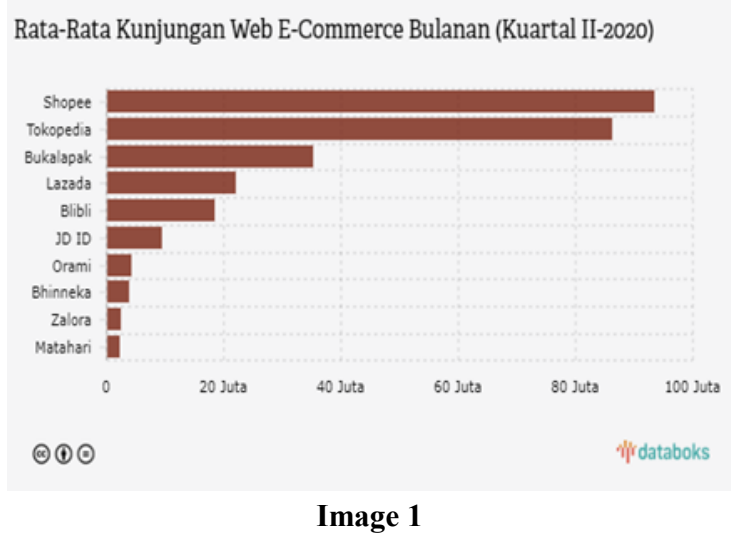

Average Monthly E-Commerce Web Visits (Quarter II2020)

Source: Databoks, 2020

Based on the data presented by Iprice proves that e-commerce is very popular with Indonesians. Moreover, during the COVID-19 pandemic people prefer to shop from home because considering there is still a virus that can infect anyone who is not disciplined when out of the house. Based on the data, the top position is owned by Shopee which has an average of 93.4 million visits per month. The next position is followed by local or original ecommerce made in Indonesia, namely Tokopedia which has an average number of visits per month as many as 86.1 million times. The third position is occupied by Bukalapak which has an average number of visits per month as much as 35.3 million times and followed by lazada as many as 22 million visitors per month (Jayani, 2020).

Based on the data presented, there is four e-commerce that has the highest average 
number of visitors per month. The four ecommerce consists of Shopee, Tokopedia, Bukalapak, and Lazada. Shopee is e-commerce created in Singapore in 2015 (Pratama Afrianto \& Irwansyah, 2021) that has the highest average number of visitors from various e-commerce, this shows that the shopee platform is favored by Indonesians even to Southeast Asians. A variety of attractive offers are offered from e-commerce, such as easy access to the desired items or want to be reviewed, even to the scope abroad. In addition, the price offered is relatively cheaper than acquiring goods through an offline store. Free shipping and cashback programs along with discounts often offered by e-commerce cause people to choose to shop online.

The COVID-19 pandemic has led entrepreneurs in small sectors, such as traditional markets, MSMEs, and businesses in the food and beverage business to turn their businesses into online businesses. Nowadays, through e-commerce people can meet their needs by simply ordering through online shopping applications, even today people can buy daily necessities that are generally available in traditional markets as well as modern markets. During the COVID-19 pandemic, people who act as consumers and manufacturers use e-commerce as a medium or a platform for them to transact. Entrepreneurs with small sectors today can come back to life if they do marketing creatively through ecommerce or other social media. Retail entrepreneurs today inevitably have to adopt technological sophistication in order to meet the needs of consumers and so that the business that has been pioneered can run, even until the COVID-19 pandemic ends.

\section{Analysis in Historical Perspective}

Pandemics such as those in the $21 \mathrm{st}$ century today when reviewed in historical perspectives in the past around 1918 appear deadly infectious disease outbreaks. The disease is called the Spanish Flu (Rusdi, 2020). The disease is caused by a virus called H1N1 which is thought to be from birds. It is believed to be the fiercest virus of the influenza virus variant in the history of health (Mansyur, 2020). There were two waves of hazing depicted in Europe and America, where the first wave occurred in 1918 in the Kansas military area and the second wave occurred in Spain which became its center in March 1918 (Cipta, 2020). It is estimated that the disease has claimed the lives of as many as 500 million people and as many as 50 million people have died.

The disease also infected Indonesia which was then controlled by the Dutch colonial government. In 1918, the global war made Indonesia infected or affected by the virus. The process of entry of the virus is believed to have started from activity at the port. This is based on the function of the port which was then the meeting place of people from various regions of the country (Khodafi, Wildayati, \& Septiyani, 2021). The virus is thought to have been carried by Europeans who came to Indonesia to meet business or trade interests. This virus causes people's activities to be paralyzed, such as port activities, education, and economic activities affected by the virus. This made the Dutch colonial government that was currently in control of Indonesia overwhelmed and it became a challenge for both the general public and the Dutch colonial government.

The Dutch colonial government created and enacted the policy in an effort to consider public health. The policy made by the Dutch colonial government was the creation of criminal laws regarding quarantine and various other provisions. The policies made by the Dutch colonial government were not immediately accepted but reaped a reaction that did not agree with the policies made by the government. This is based on the impact that will later arise as a result of the enactment of the policy. However, the Dutch colonial government, which considered public health interests, chose to prioritize public health aspects, although the policy went through a long process, the Dutch colonial government continued to enforce the policy.

When reviewed through economic aspects, the impact of the spread of Spanish Flu disease in Indonesia at that time was a change in the order of workers, for example, railway workers, plantations, government, and ports. In 1919, as many as 180 indigenous workers took time off work, and the following year as many as 167 European workers took time off because at that time many European workers contracted Spanish Flu disease. Workers in shipping and ports also felt the impact. The port which is the meeting place of traders or residents from different regions to conduct interests experienced a long delay in shipping. Government policy recommends conducting health tests on migrants with fairly strict procedures at the port. The government's recommendations on the vetting of migrants caused the port to suffer losses.

Various policies set by the Dutch colonial 
government showed that the government showed seriousness in minimizing the spread of Spanish flu. The Dutch colonial government preferred to attach importance to the public health aspect by making various policies. These policies include the creation of legislation that contains the threat of punishment for people who commit violations of the policy. This can be used as a reference to overcome the impacts that occur in the current pandemic, namely the COVID-19 pandemic. Where the government should consider various aspects in making policy so as not to cause a reaction or negative things from the public about the impact that may be caused, although every policy there must be a counter-opinion on the policy.

\section{CONCLUSION}

Based on the results and discussion explained abover, thus it can be concluded that the COVID-19 pandemic is a pandemic caused by the spread of severe acute respiratory syndrome coronavirus 2 (SARS-CoV-2) virus in various countries around the world. With this pandemic, aspects of life are changing. In terms of the economy, there are some companies that forcibly lay off or terminate mass employment rights against their employees. This is because the company experienced a decrease in revenue which is a result of the COVID-19 pandemic. Termination of employment rights can lead to an increase in the poverty and unemployment rate that occurs. These impacts can be minimized by opening a business through ecommerce as a container or place to market products. E-commerce can help Indonesia's economy during the pandemic, where there is an increase in the number of consumer visits to e-commerce sites or applications during the COVID-19 pandemic. Consumers are believed to be more comfortable doing shopping activities online because it is considered more practical and effective, both in terms of cost, energy, and time. Therefore, economic strengthening can be done through the growth of e-commerce as a means or a forum for small micro-entrepreneurs. When viewed from a historical perspective, the COVID-19 pandemic bears similarities to the outbreak that occurred in the early 20th century, namely the Spanish Flu. The outbreak was caused by the H1N1 virus believed to be from birds. The disease spread to all corners of the world, even Indonesia. In Indonesia, there are impacts resulting from the outbreak. Therefore, the Dutch colonial government that was in control of Indonesia imposed several policies in minimizing the spread of Spanish Flu disease. Therefore, this study is recommended for readers who want to know the role of ecommerce during the COVID-19 pandemic and the state of the COVID-19 pandemic which has similarities to the Spanish Flu outbreak when viewed from a historical perspective.

\section{REFERENCE}

Ayu, S., \& Lahmi, A. (2020). Peran E-Commerce Terhadap Perekonomian Indonesia Selama Pandemi Covid-19. Jurnal Kajian Manajemen Bisnis, 9(2), $114 . \quad$ https:// doi.org/10.24036/jkmb.10994100

Bahtiar, R. A. (2020). Potensi, Peran Pemerintah, dan Tantangan dalam Pengembangan ECommerce di Indonesia [Potency, Government Role, and Challenges of ECommerce Development in Indonesia]. Ekonomi \& Kebijakan Publik, 11(1), 13-25. https://doi.org/http://dx.doi.org/10.22212/ jekp.v11i1.1485

Baum, D. (1999). Business Links. Oracle Magazine, 8(3), 36-44.

Bhatti, A., Akram, H., \& Khan, A. U. (2020). ECommerce Trends During COVID-19 Pandemic. International Journal of Future Generation Communication and Networking, 13(2), 1449-1452. Retrieved from https://sersc.org/journals/index.php/ IJFGCN/article/view/24523

Cipta, S. E. (2020). Upaya Penanganan Pemerintah Hindia Belanda Dalam Menghadapi Berbagai Wabah Penyakit dI Jawa 19111943. Equilibrium: Jurnal Pendidikan, 8(2), 162-169. https://doi.org/10.26618/ equilibrium.v8i2.3281

Fauzi, F., Al-Khowarizmi, A.-K., \& Muhathir, M. (2020). The e-Business Community Model is Used to Improve Communication Between Businesses by Utilizing Union Principles. Journal of Informatics and Telecommunication Engineering, 3(2), 252257. https://doi.org/10.31289/jite.v3i2.3260

Handayani, R. T., Arradini, D., Darmayanti, A. T., Widiyanto, A., \& Atmojo, J. T. (2020). Pandemic Covid-19, Body Immunity Response, and Herd Immunity. Jurnal Ilmiah Stikes Kendal, 10(3), 373-380. Retrieved from https:// journal.stikeskendal.ac.id/index.php/PSKM/ article/view/830

Jayani, D. H. (2020). Peta Persaingan E-Commerce Indonesia pada Kuartal II-2020. Retrieved from Databoks website: www.databoks.katadata.co.id

Juaningsih, I. N., Consuello, Y., Tarmidzi, A., \& NurIrfan, D. (2020). Optimalisasi Kebijakan Pemerintah dalam penanganan Covid-19 terhadap Masyarakat Indonesia. SALAM: Jurnal Sosial Dan Budaya Syar-I, 7(6), 509- 
$518 . \quad$ https://doi.org/10.15408/ sjsbs.v7i6.15363

Khodafi, M., Wildayati, W., \& Septiyani, R. E. (2021). Kilas-Balik Wabah di Indonesia: Mengurai Kembali Pandemi COVID-19 Melalui Peristiwa Flu Spanyol 1918-1920. SULUK: Jurnal Bahasa, Sastra, Dan Budaya, 2(2), 91-106. https:// doi.org/10.15642/suluk.2020.2.2.91-106

Laming, S. (2020). Tren E-Commerce Pada Era Pandemi COVID-19. Jurnal Penelitian Humano, 11(2), 55-63. https://doi.org/http:// dx.doi.org/10.33387/hjp.v11i2.2323

Leatemia, S. Y. (2020). ADOPSI E-COMMERCE PADA UMKM DI ERA PANDEMI COVID -19 (Studi Kasus pada UMKM di Kota Ambon). Soso-Q Jurnal Manajemen, 8(2), 1 $-11 . \quad$ https://doi.org/http:// dx.doi.org/10.30598/sosoq.v8i2.1144

Mandasari, I. A. C. S., \& Pratama, I. G. S. (2020). The Use of E-Commerce During COVID-19 Pandemic Towards Revenue and Volume of MSMEs Sales. International Research Journal of Management, IT and Social Sciences, 7(6), 124-130. https:// doi.org/10.21744/irjmis.v7n6.1022

Mansyur, M. (2020). Pandemi Flu Spanyol di Banjarmasin, Karesidenan Borneo bagian Selatan dan Timur (1918-1920). Y upa: Historical Studies Journal, 4(1), 9-19. https://doi.org/10.30872/yupa.v4i1.205

Pratama Afrianto, A., \& Irwansyah, I. (2021). Eksplorasi Kondisi Masyarakat Dalam Memilih Belanja Online Melalui Shopee Selama Masa Pandemi Covid-19 di Indonesia. Jurnal Teknologi Dan Sistem Informasi Bisnis, 3(1), 10-29. https:// doi.org/10.47233/jteksis.v3i1.181

Purwanto, A. (2020). Studi Eksplorasi Dampak Work From Home ( WFH ) Terhadap Kinerja Guru Selama Pandemi Covid-19. EduPsyCouns: Journal of Education, Psychology and Counseling, 2(1), 92-100. Retrieved from https:/ummaspul.ejournal.id/Edupsycouns/article/view/418

Ridlo, I. A. (2020). Pandemi COVID-19 dan Tantangan Kebijakan Kesehatan Mental di Indonesia. INSAN Jurnal Psikologi Dan Kesehatan Mental, 5(2), 162. https:// doi.org/10.20473/jpkm.V5I22020.162-171

Rusdi, R. (2020). Pandemi Penyakit dalam Sejarah dan Dampaknya Terhadap Gejolak Sosial Politik. Diakronika, 20(1), 50. https:// doi.org/10.24036/diakronika/vol20-iss1/146

Saturwa, H. N., Suharno, S., \& Ahmad, A. A. (2021). The Impact of Covid-19 Pandemic on MSMEs. Jurnal Ekonomi Dan Bisnis, 24 (1), 65-82. https://doi.org/10.24914/ jeb.v24i1.3905

Siahaan, M. (2020). Dampak Pandemi Covid-19 Terhadap Dunia Pendidikan. Jurnal Kajian Ilmiah, 1(1), 73-80. https:// doi.org/10.31599/jki.v1i1.265
Sidiq U, C. M. (2019). Metode Penelitian Kualitatif di Bidang Pendidikan. Ponorogo: CV Nata Karya.

Susilo, A., Rumende, C. M., Pitoyo, C. W., Santoso, W. D., Yulianti, M., Herikurniawan, H., ... Yunihastuti, E. (2020). Coronavirus Disease 2019: Tinjauan Literatur Terkini. Jurnal Penyakit Dalam Indonesia, 7(1), 45. https://doi.org/10.7454/ jpdi.v7i1.415

Suyanto, M. (2003). Strategi Periklanan pada ECommerce Perusahaan Top Dunia. Yogyakarta: Andi.

Tuwu, D. (2020). Kebijakan Pemerintah Dalam Penanganan Pandemi Covid-19. Journal Publicuho, 3(2), $267 . \quad \mathrm{https}: / /$ doi.org/10.35817/jpu.v3i2.12535

Valerisha, A., \& Putra, M. A. (2020). Pandemi Global Covid-19 Dan Problematika NegaraBangsa: Transparansi Data Sebagai Vaksin Socio-Digital? Jurnal Ilmiah Hubungan Internasional, O(0), 131-137. https:// doi.org/10.26593/jihi.v0i0.3871.131-137

Yamali, F. R., \& Putri, R. N. (2020). Dampak Covid-19 Terhadap Ekonomi Indonesia. Ekonomis: Journal of Economics and Business, 4(2), $384 . \quad$ https:// doi.org/10.33087/ekonomis.v4i2.179 